Original Research Paper

\title{
Studies on Bacterial Pathogens in Some Marine Fishes in EL- Mansoura, Egypt
}

\author{
${ }^{1}$ Elsayed Mahmoud Ezzat, ${ }^{2}$ Essawy Mahmoud, ${ }^{1}$ Shabana Iman Ibrahim, \\ ${ }^{3}$ Abou El-Atta Mohamed and ${ }^{2}$ EL-Banna Noha \\ ${ }^{I}$ Department of Bacteriology, Faculty of Veterinary Medicine, \\ Immunology and mycology, Suez Canal University, Egypt \\ ${ }^{2}$ Department of Microbiology, Animal Health Research Institute, Egypt \\ ${ }^{3}$ Department of Fish Health, Central laboratory for Aquaculture Research, Egypt
}

Article history

Received: 15-02-2018

Revised: $18-03-2018$

Accepted: 26-03-2018

Corresponding Author: Shabana Iman Ibrahim Department of Bacteriology, Faculty of Veterinary Medicine, Immunology and mycology, Suez Canal University, Egypt Email: imanibrahim50@yahoo.com

\begin{abstract}
A total of 200 marine fish of two different species (100 Tilapia zillii and100 Mugil capito) were randomly collected from different markets, during different seasons. Fish subjected to clinical, postmortem and bacteriological studies. The common clinical signs were darkness of the skin, hemorrhage in the fins base, eyes and different parts of the body, abdominal distention, congestion in gills and increasing in mucous secretion. The Post Mortem findings showed white serous fluid in the abdominal cavity and sometimes tinged with blood and pale or congested liver, kidney and spleen. The bacteriological examination, revealed that the prevalence of bacterial pathogens among naturally infected marine fishes were A. hydrophila $(52 ; 39.39 \%), V$. alginolyticus $(38 ; 28.79 \%)$, Ps. fluorescens $(24 ; 18.18 \%), V$. cholerae $(10 ; 7.58 \%)$ and Ps. aeruginosa (8; $6.06 \%)$. The highest prevalence of bacterial infection was during summer $(33.33 \%)$ followed by spring $(24.42 \%)$, then autumn $(21.97 \%)$, while the least prevalence was in the winter season $(20.46 \%)$. A. hydrophila was highly pathogenic to $T$. zillii causing $100 \%$ mortality followed by $V$. alginolyticus causing (90\%) mortality, then Ps. fluorescens (80\%), Ps. aeruginosa $(60 \%)$ while $V$. cholerae was non-pathogenic. The results of antibiogram revealed that ciprofloxacin and nalidixic acid were effective against $A$. hydrophila, while ciprofloxacin and rifampicin were effective against $P$ s. fluorescens. Ciprofloxacin and amikacin were effective against Ps. aeruginosa. While $V$. alginolyticus was highly sensitive to ciprofloxacin. High prevalence of pathogenic and resistant bacterial strains among marine fishes in Egypt, requires strict control measures from the responsible authorities.
\end{abstract}

Keywords: Marine, Fish, Bacteria, Season, Antibiotics

\section{Introduction}

Aquaculture is an important source of high nutritive value, cheap animal proteins and it becomes an important economic activity in many countries. In this way, the Egyptian Government within the strategy of the food paid special interest to fish meat and within this strategy fish aquaculture and fish industry are one of the main sources of the Egyptian. In the near future, the limitation of aquaculture development in Egypt will be due to water resources especially freshwater. Thus, mariculture is the alternative solution.
Aeromonas, Vibrio and Pseudomonas species are among the economically important bacterial fish diseases affecting marine fish cultures (Falaise et al., 2016).

The infectious bacterial diseases in marine fish affected by the following: (i) Significant economic losses in cultured fish are caused by a relatively small number of pathogenic bacteria; (ii) Several typical of fresh water aquaculture diseases turns as marine culture serious problems; (iii) The disease clinical signs depend on the host species, age; (iv) Absence of any correlation between the external and internal signs; and (v) The lack of the stressful conditions, resulted in increasing the 
mortality and the severity of the disease in cultured fish than that in wild fish (Toranzo et al., 2005).

The use of antibiotics in the aquaculture leads to a variety of public health hazards. The greatest potential risk to public health is thought to be the transfer of resistant organisms through consumption of contaminated fish, the development and spread of antimicrobial resistant bacteria and resistance genes and the dissemination of the resistance genes by horizontal gene transfer (Lukkana et al., 2012; Aly, 2013).

The bacterial diseases in marine fish are responsible for important economic losses worldwide. So the present study aimed to isolate and identify the bacterial pathogens in some marine fishes and evaluate the seasonal variation, prevalence in different organs and their antibiogram against the most commonly used antibiotics in maricultures. In addition, an experimental infection was performed to determine the mortality rate caused by different bacterial pathogens.

\section{Material and Methods}

\section{Sampling}

A total of 200 marine fish of two different marine fish species (100 Tilapia zillii and 100 Mugil capito) were freshly collected from different markets in ELMansoura city, during the four seasons. A total of twenty-five fish of each species were collected in each season. Clinical and postmortem examination were carried out according to (Schaperclaus et al., 1992).

\section{Isolation of Suspected Bacteria}

Samples from liver, kidney, spleen and gills were cultured on tryptic soy broth, tryptic soy agar (oxoid) supplemented with $2 \% \mathrm{NaCl}$, thiosulphate citrate bile salt agar (oxoid), Aeromonas base media supplemented with ampicillin and Pseudomonas agar base media supplemented with $2 \% \mathrm{NaCl}$ and $2 \%$ glycerin. The plates were incubated at $28^{\circ} \mathrm{C}$ for $1-2$ days.

\section{Identification of the Isolated Bacteria}

Bacterial isolates were stained with Gram's stain to examine their morphology. The isolates then biochemically identified according to (Bergey's, 2005). The analytical profile index of API20 E system was used to the final confirmation of the bacterial isolates identification (Buller, 2004).

\section{Antibiotic Sensitivity}

The sensitivity of the isolated bacterial strains to antibiotics was performed using the disc diffusion method on Muller's Hinton agar medium against the oxytetracycline, ampicillin, amoxicillin, lincomycin, ciprofloxacin, colistin sulfate, nalidixic acid, amikacin, rifampicin and erythromycin (Schaperclaus et al., 1992).

\section{Experimental Infection}

A total of 70 live and apparently healthy $T$. zillii fish with an average body weight $20 \pm 5 \mathrm{~g}$, were obtained from EL Abbassa fish farm, EL sharkia, Egypt. They were used for experimental infection with $A$. hydrophila, $P S$. fluorescens, Ps. aeruginosa, $V$. alginolyticus and $V$. cholerae which isolated from naturally infected marine fish. The Fish were maintained in glass aquaria supplied with well aerated dechlorinated tap water with the addition of salt to be acclimated. All experimental fish were fed with a commercial ration at a rate of $5 \%$ body weight per day.

Fish were divided into seven groups (10 fish of each) and a bacterial suspension were prepared for $\mathrm{I} / \mathrm{P}$ injection (Austin and Austin, 1999). Five groups were $\mathrm{I} / \mathrm{P}$ injected with a bacterial suspension prepared separately from each species (Ps. aeruginosa, $A$. hydrophila, $V$. alginolyticus, Ps. fluorescence and $V$. cholerae at a dose of $0.2 \mathrm{~mL}$ of $\left(3 \times 10^{7} \mathrm{CFU}\right)$. The sixth group was intra-peritoneal injected with $0.2 \mathrm{ml}$ of saline containing $V$. cholerae $\left(2.5 \times 10^{8} \mathrm{CFU} \mathrm{m}{ }^{-1}\right)$ (Austin and Austin, 2007) the last group was left as control and injected I/P with $0.2 \mathrm{ml}$ sterile saline (Table 5). Fish observed daily for 1-2 weeks and the clinical signs and mortalities were recorded. Freshly dead fish were examined for postmortem gross lesions. Pathogenic bacteria re-isolated from dead and scarified fish.

\section{Statistical Analysis}

Statistical analysis was performed using the Statistical Package for the Social Sciences version 20.0 (SPSS inc. Chicago, USA). Pearson correlation coefficient was used to determine the association between the prevalence of bacterial pathogens during the four seasons. A $p$-value of 0.05 or less was considered as statistically significant.

\section{Results}

\section{Clinical and Postmortem Examination}

The naturally infected fish showed the darkness of the external body surface, an opacity of eye, increased mucous secretion, exophthalmia and some fish showed hemorrhages in the eye and large irregular hemorrhagic areas into many parts of the body, at the base of fins, on gills cover, at the anal region and anal fin. There was abdominal distention observed in some fish (Fig. 1). The Postmortem examination showed white serous fluid in the abdominal cavity, some tinged with blood. The liver appeared pale anemic, friable with some hemorrhagic patches and pinpoint hemorrhagic on liver surface. Kidney was congested and slightly enlarged. The intestine of some fish was hemorrhagic, inflamed with severe congestion. The spleen was enlarged and congested and in some cases appeared pale and in other cases appeared normal. In some fish hemorrhagic areas appeared in the abdominal wall and on the peritoneum (Fig. 2). 


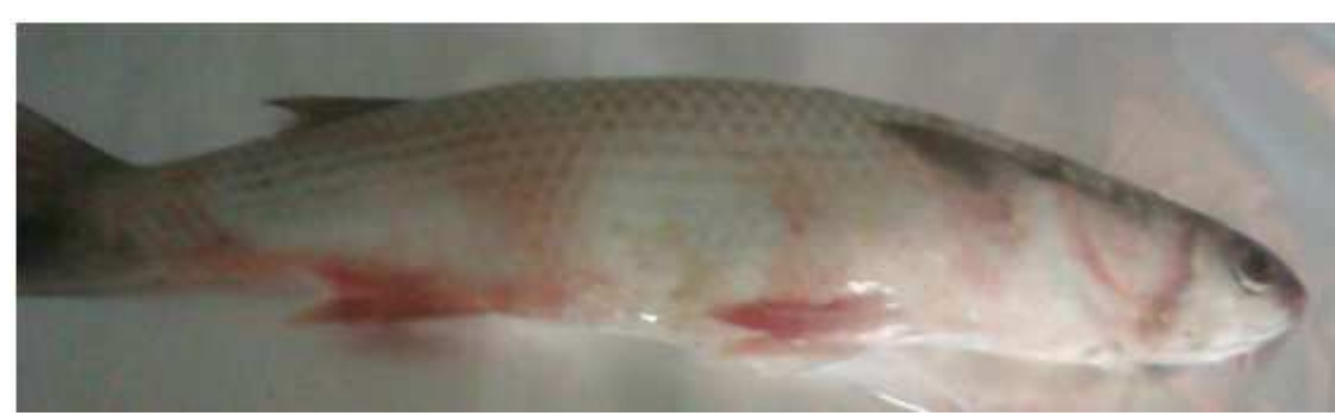

Fig. 1: Diseased M. capito with diffused hemorrhage on body surface and on anal and ventral fine

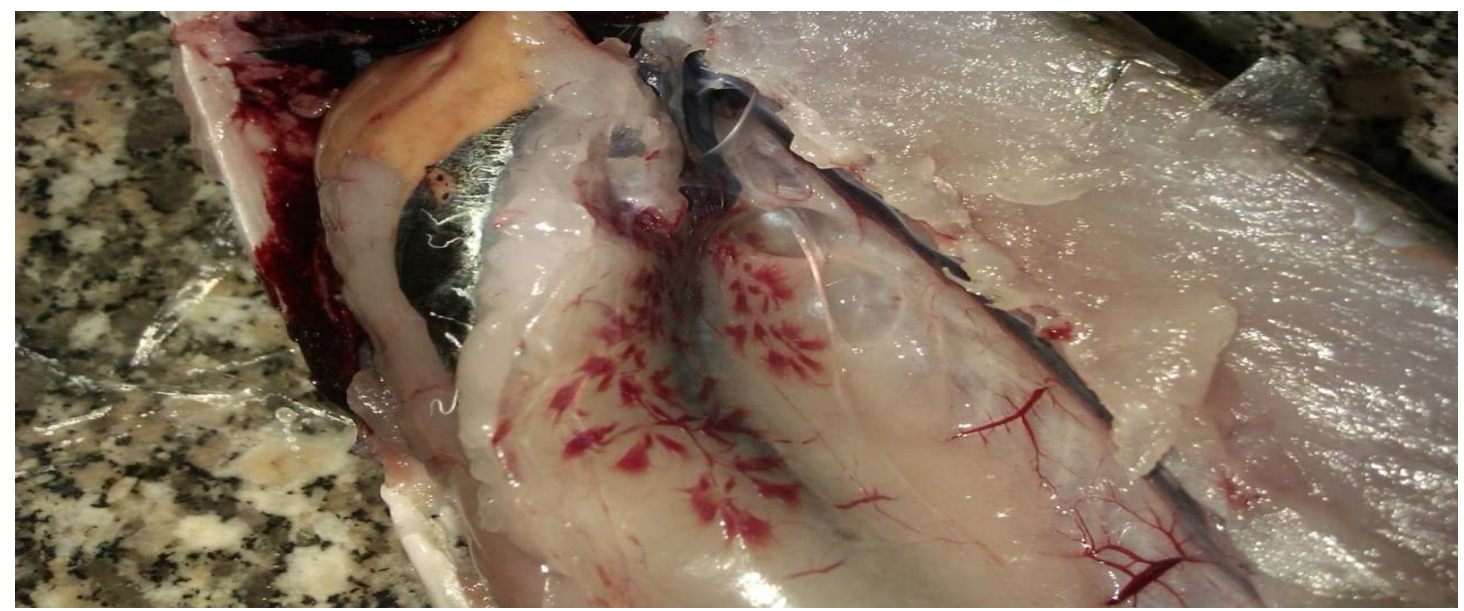

Fig. 2: Diseased M. capito showed hemorrhages in peritoneum

\section{Bacteriological Examination}

The bacteriological examination showed the isolation of 132 Gram-negative isolates which identified morphologically, biochemically and confirmed by API20 into A. hydrophila, Ps. fluorescens, Ps. aeruginosa, $V$. alginolyticus and $V$. cholerae (Table 1). A total of (22; $14.29 \%$ ) isolates were oxidase-negative and (132; $85.71 \%$ ) were oxidase-positive isolates. Among the oxidase-positive isolates, $A$. hydrophila represented (52; $39.39 \%)$, followed by $V$. alginolyticus $(38 ; 28.79 \%)$, Ps. fluorescens $(24 ; 18.18 \%)$, V. cholerae $(10 ; 7.58 \%)$ and Ps. aeruginosa $(8 ; 6.06 \%)$ (Table 2$)$.

The results of bacterial isolates distribution in different organs and tissues of the examined marine fish are depicted in Table 3. The highest rate of A. hydrophila was in liver $(44.23 \%)$, while the minimal prevalence recorded in gills $(7.69 \%)$. Ps. fluorescens was isolated mainly from kidney (50\%), followed by liver (25\%) and spleen $(8.33 \%)$. Ps. aeruginosa was isolated equally from liver and kidney (37.5\%), followed by spleen and gills (12.5\%). V. alginolyticus was isolated mainly from liver $(36.84 \%)$ and at a lower rate from gills $(7.89 \%)$. The highest prevalence of $V$. cholerae was in the kidney $(40 \%)$, while the least prevalence was in gills $(10 \%)$.

\section{Seasonal Variation}

The seasonal prevalence of bacterial pathogens among the naturally infected marine fish was the highest during summer $(33.33 \%)$, followed by the spring $(24.24 \%)$, then autumn $(21.97 \%)$, in contrast, the minimal prevalence was during winter $(20.46 \%)$ (Table 4$)$. The overall prevalence of different bacterial pathogens during summer was statistically significant compared to other seasons ( $\mathrm{p}$ values $<0.05)$. A. hydrophila highest prevalence was during summer season 18 (15.4\%), while Ps. fluorescens not reported in summer. Ps. aeruginosa was isolated only during spring and summer. $V$. alginolyticus highest prevalence was also during summer. $V$. cholerae reported during different seasons but not during winter.

\section{Antibiotic Sensitivity}

The results of antibiotic sensitivity revealed that ciprofloxacin and nalidixic acid were more effective against $A$. hydrophila, while ciprofloxacin and rifampicin more effective against Ps. fluorescens. ciprofloxacin and amikacin were effective against $P$ s. aeruginosa. $V$. alginolyticus was highly sensitive to ciprofloxacin. On the other hand, the bacterial isolates showed resistance against ampicillin, amoxicillin, erythromycin and oxytetracycline. 
Elsayed Mahmoud Ezzat et al. / American Journal of Agricultural and Biological Sciences 2018, 13 (1): 9.15 DOI: 10.3844/ajabssp.2018.9.15

Table 1: The biochemical and morphological characters of isolated bacteria from examined marine fish

\begin{tabular}{|c|c|c|c|c|c|c|}
\hline & & A. hydrophila & Ps. fluorescens & Ps. aeruginosa & V. alginolyticus & V. Cholerae \\
\hline 1. & Gram stain & - & - & - & - & - \\
\hline 1. & Shape & Short rod. & Short rod & Short rod & vebrionic bacilli & vebrionic bacilli \\
\hline 2. & Motility & + & + & + & + & + \\
\hline 3. & Cytochrome Oxidase. (Ox) & + & + & + & + & + \\
\hline 4. & Catalase Test & + & + & + & + & + \\
\hline 5. & B-Galactosidase Production (OPNG) & + & - & - & - & + \\
\hline 6. & Arginine Dihydrolase production (ADH) & - & + & + & - & - \\
\hline 7. & Lysine Decarboxylase production (LDC) & - & + & - & + & - \\
\hline 8. & Ornithine Decarboxylase production (ODC) & + & + & - & + & + \\
\hline 9. & Citrate utilization (CIT) & - & + & + & - & - \\
\hline 10. & $\mathrm{H}_{2} \mathrm{~S}$ production $\left(\mathrm{H}_{2} \mathrm{~S}\right)$ & - & - & - & - & - \\
\hline 11. & Urease Production (URE) & - & - & + & - & - \\
\hline 12. & Tryptophan Deaminase Production (TDA) & - & - & - & - & - \\
\hline 13. & Indole production (IND) & + & - & - & + & + \\
\hline 14. & Acetoin production (VP) & - & - & + & - & + \\
\hline 15. & Gelatinase production (GEL) & + & - & + & + & + \\
\hline 16. & Acid from glucose & + & - & - & + & $\mathrm{v}$ \\
\hline 17. & Acid from manitole & + & - & - & + & + \\
\hline 18. & Acid from inositol & + & - & - & - & - \\
\hline 19. & Acid from sorbitol & + & - & - & - & - \\
\hline 20. & Acid from rhaminos & - & - & - & - & - \\
\hline 21. & Acid from sacrose & + & - & - & + & + \\
\hline 22. & Acid from melobiose & - & - & - & - & - \\
\hline 23. & Acid from amylase & + & - & - & - & - \\
\hline
\end{tabular}

Table 2: Prevalence of Gram-negative, oxidase positive bacterial isolates in examined marine fish

\begin{tabular}{llll}
\hline A. hydrophila & Ps. fluorescens & Ps. aeruginosa & V. alginolyticus \\
\hline $52(39.39 \%)$ & $24(18.18 \%)$ & $8(6.06 \%)$ & $38(28.79 \%)$
\end{tabular}

Table 3: Incidence of Gram-negative bacterial species from examined tissues and organs of marine fish

\begin{tabular}{|c|c|c|c|c|c|c|c|c|c|c|c|c|}
\hline \multirow[b]{2}{*}{ Organ } & \multicolumn{2}{|c|}{ A. hydrophila } & \multicolumn{2}{|c|}{ Ps. fluorescens } & \multicolumn{2}{|c|}{ Ps. aeruginosa } & \multicolumn{2}{|c|}{ V. alginolyticus } & \multicolumn{2}{|c|}{ V. Cholerae } & \multicolumn{2}{|c|}{ Total } \\
\hline & No. & $\%$ & No. & $\%$ & No. & $\%$ & No. & $\%$ & No. & $\%$ & No. & $\%$ \\
\hline Liver & 23 & 44.230 & 6 & 25.00 & 3 & 37.50 & 14 & 36.84 & 2 & 20.00 & 48 & 36.36 \\
\hline Kidney & 19 & 36.540 & 12 & 50.00 & 3 & 37.50 & 12 & 31.58 & 4 & 40.00 & 50 & 37.84 \\
\hline Spleen & 6 & 11.540 & 2 & 8.33 & 1 & 12.50 & 9 & 23.68 & 3 & 30.00 & 21 & 15.91 \\
\hline Gills & 4 & 7.690 & 4 & 16.67 & 1 & 12.50 & 3 & 7.89 & 1 & 10.00 & 13 & 9.85 \\
\hline Total & 52 & 39.390 & 24 & 18.18 & 8 & 6.06 & 38 & 28.79 & 10 & 7.58 & 132 & 100.00 \\
\hline
\end{tabular}

Table 4: Seasonal prevalence of Gram-negative bacterial species in examined marine fish

\begin{tabular}{|c|c|c|c|c|c|}
\hline Bacterial isolates & Winter & Spring & Summer* & Autumn & Total \\
\hline A. hydrophila & $14(26.9 \%)$ & $12(23.1 \%)$ & $18(34.6 \%)$ & $8(15.4 \%)$ & $52(39.39 \%)$ \\
\hline Ps. fluorescens & $8(33.3 \%)$ & $8(33.3 \%)$ & 0 & $8(33.3 \%)$ & $24(18.18 \%)$ \\
\hline Ps. aeruginosa & 0 & $4(50 \%)$ & $4(50 \%)$ & 0 & $8(6.06 \%)$ \\
\hline$V$. alginolyticus & $5(13.2 \%)$ & $7(18.4 \%)$ & $16(42.2 \%)$ & $10(26.3 \%)$ & $38(28.79 \%)$ \\
\hline$V$. cholerae & 0 & $1(10 \%)$ & $6(60 \%)$ & $3(30 \%)$ & $10(7.59 \%)$ \\
\hline Total & $27(20.45 \%)$ & $32(24.24 \%)$ & $44(33.33 \%)$ & $29(21.97 \%)$ & $132(100 \%)$ \\
\hline
\end{tabular}

* Statistically significant (p-values $<0.05$ )

\section{Experimental Infection}

The clinical signs of the disease appeared after $24 \mathrm{hrs}$ of fish injection with the pathogenic isolates $(A$. hydrophila, Ps. fluorescens, Ps. aeruginosa and $V$. alginolyticus) and the signs included inflammatory changes at site of injection, hemorrhages all over the body, bilateral distention of abdomen, congested liver, kidney and spleen. The pathogenic isolates were reisolated from all freshly dead and scarified infected fish. The mortality rates caused by A. hydrophila, Ps. fluorescens, Ps. aeruginosa, $V$. alginolyticus was $100 \%, 80 \%, 60 \%$ and $90 \%$ respectively. While the I/P infected fish groups with two different concentrations of $V$. cholerae showed neither clinical signs nor mortalities (Table 5). 
Table 5: Mortality rates of the experimentally infected fish

\begin{tabular}{|c|c|c|c|c|c|c|c|c|c|c|}
\hline \multirow[b]{2}{*}{ Group* } & \multirow[b]{2}{*}{ Dose per fish } & \multicolumn{7}{|c|}{ Dead fish during 7 days after Injection of pathogenic bacteria } & \multirow{2}{*}{$\begin{array}{l}\text { No. of } \\
\text { dead fish }\end{array}$} & \multirow{2}{*}{$\begin{array}{l}\text { Mortality } \\
\text { rate } \%\end{array}$} \\
\hline & & 1 & 2 & 3 & 4 & 5 & 6 & 7 & & \\
\hline 1 & $\begin{array}{l}\text { A. hydrophila } \\
0.2 \mathrm{~mL} \text { of } 3 \times 10^{7} \mathrm{CFU}\end{array}$ & 3 & 3 & 3 & 1 & - & - & - & 10 & $100 \%$ \\
\hline 2 & $\begin{array}{l}\text { Ps. fluorescens } \\
0.2 \mathrm{~mL} \text { of } 3 \times 10^{7} \mathrm{CFU}\end{array}$ & 2 & 2 & 1 & 2 & 1 & - & - & 8 & $80 \%$ \\
\hline 3 & $\begin{array}{l}\text { Ps. aeruginosa } \\
0.2 \mathrm{~mL} \text { of } 3 \times 10^{7} \mathrm{CFU}\end{array}$ & 0 & 2 & 2 & 2 & - & - & - & 6 & $60 \%$ \\
\hline 4 & $\begin{array}{l}\text { V. alginolyticus } \\
0.2 \mathrm{~mL} \text { of } 3 \times 10^{7} \mathrm{CFU}\end{array}$ & 2 & 3 & 3 & 1 & - & - & - & 9 & $90 \%$ \\
\hline 5 & $\begin{array}{l}\text { V. cholerae } \\
0.2 \mathrm{~mL} \text { of } 3 \times 10^{7} \mathrm{CFU}\end{array}$ & - & - & - & - & - & - & - & - & $0 \%$ \\
\hline 6 & $\begin{array}{l}\text { V. cholerae } \\
0.2 \mathrm{~mL} \text { of } 2.5 \times 10^{8} \mathrm{CFU}\end{array}$ & - & - & - & - & - & - & - & - & $0 \%$ \\
\hline 7 & $\begin{array}{l}\text { Control group } \\
0.2 \mathrm{~mL} \text { of sterile saline }\end{array}$ & - & - & - & - & - & - & - & - & $0 \%$ \\
\hline
\end{tabular}

* (10 fish each)

\section{Discussion}

Marine fish are susceptible to a wide variety of bacterial pathogens. In the present study, naturally infected marine fish (M. capito and $T$. zilii) were clinically examined and found to have darkness of the external body surface, opacity of eye, exophthalmia and some fish showed hemorrhages in eye, scales detachment and large irregular hemorrhagic areas into many parts of the body, at base of fins, anal fin and caudal peduncle. Postmortem findings of most of the examined fish pointed out that liver appeared to be pale anemic, friable with some hemorrhagic patches on its surface and in some cases appear congested. Kidney and spleen were congested and slightly enlarged and in some cases pale. In some fish appeared hemorrhagic areas in the abdominal wall. Our clinical and Postmortem findings were in accordance with what was mentioned by Toranzo et al. (2005).

The most prevalent bacterial pathogens affecting fish worldwide are Aeromonas and Pseudomonas (Kayansamruaj et al., 2017) in addition to genus Vibrio especially $V$. alginolyticus, $V$. cholerae (non-O1), $V$. vulnificus (Biotype 2), V. anguillarum (Kannapiran et al., 2009). In the present study, bacteriological examination identified A. hydrophila, Ps. fluorescens, Ps. aeruginosa, $V$. alginolyticus and $V$. cholerae. Among the bacterial isolates A. hydrophila is the most prevalent (39.39\%), followed by $V$. alginolyticus $(28.79 \%)$ and $P S$. fluorescens $(18.18 \%)$ and these results were in accordance with Zorrilla et al. (2003) who isolated the bacterial pathogens as follow: Vibrio (69.90\%), Pseudomonas spp. and Aeromonas spp., in which $V$. alginolyticus was the most identified species (21.35\%) and with Ullmann et al. (2005) who demonstrated that among the bacterial pathogens $A$. hydrophila had the highest prevalence (67\%), followed by $A$. caviae (26.1\%) and A. sobria (6.0\%). Also (Abd-El-Malek, 2017) who isolated ps. fluorescens from naturally infected Mugil species with a prevalence rate of $21.33 \%$. Thomas et al. (2014) isolated 12 (15\%) Ps. aeruginosa out of 80 Pseudomonas spp. from marine fish. Outbreaks of $A$. hydrophila were usually associated with environmental changes and other Stresses such as, sudden change in temperature, overcrowding, poor nutrition and other infections that made stress on fish and increase its susceptibility to the infection (Hayes, 2000).

Regarding, the seasonal prevalence of $A$. hydrophila the result highlighted that $A$. hydrophila highest prevalence was recorded in summer $(34.6 \%)$, followed by winter season $(26.9 \%)$, spring $(23.1 \%)$ and autumn (15.4\%). Aeromonas dynamics exhibited a seasonal prevalence in natural seawater. Aeromonads decreased very rapidly in sea water during the cold period from the end November to April (Maalej et al., 2003). Our findings are agreed with Nam and Joh (2007) who demonstrated that $A$. hydrophila was dominant in August and the density of Aeromonas isolates was ten times higher in November than in August because Aeromonas was both psychrophilic as well as mesophilic strains.

On the other hand Ps. fluorescens prevalence was equal during winter, autumn and spring. While not recorded in the summer season. Ps. fluorescens propagate and exerts infection at low temperature (Eissa et al., 2013). These results were in accordance with (Blanco et al., 2002) who illustrated that the proteinase activity of Pseudomonas spp. increase in low temperature. Wang et al. (2017) reported that Pseudomonas were isolated mainly in cold months. while these results disagreed with (Miguéis et al., 2016) who reported a lower prevalence of Pseudomonas in winter than in summer. In contrast, our results disagreed with Thomas et al. (2014) who 
isolated Pseudomonas spp. with a significant difference among the four seasons, $43.33 \%$ in spring, $24.44 \%$ in summer, $21.11 \%$ in autumn and $17.77 \%$ in winter. While, the highest prevalence of Ps.aeruginosa was recorded in spring (12.5\%), followed by summer $(9.09 \%)$. But not reported in winter and autumn.

The highest prevalence of $V$. alginolyticus was recorded in summer $(42.2 \%)$, then autumn $(26.3 \%)$, followed by spring $(18.4 \%)$ and winter $(13.2 \%)$. The obtained results of seasonal prevalence of $V$. alginolyticus were higher than what reported by Di et al. (2017) who isolated $V$. alginolyticus at a prevalence of $8.57 \%$ in summer, $5.30 \%$ in autumn, $2.04 \%$ in spring and $0.81 \%$ in winter. This was in a disagreement with (Wang et al., 2017) who reported that V. alginolyticus were not associated with a particular season.

Concerning to the rate of bacterial isolates recovery from various organs, our investigation demonstrated that the prevalence of total bacterial isolates was $(37.84 \%)$ in the kidney so it is the most predominant site for isolation of bacterial pathogens that causing septicemia as it is considered as one of the main hematopoietic organs of fish. Followed by the liver $(36.36 \%)$, then spleen $(15.91 \%)$ and finally gills $(9.85 \%)$ and this result nearly agreed with (Mahmoud et al., 2016) who concluded that the bacterial infections affect hematopoietic system mainly liver, kidney and spleen.

Antibiogram sensitivity results cleared that ciprofloxacin and nalidixic acid were highly effective against $A$. hydrophila and these results agreed with (Grande et al., 2018). While ciprofloxacin and rifampicin were more effective against Pseudomonas spp. and these results similar to that detected by (Lee and Wendy, 2017). On the other hand, $V$. alginolyticus was highly sensitive to ciprofloxacin and our results supported with that obtained by (Schmidt et al., 2017).

\section{Conclusion}

It was concluded that the highest prevalence of bacterial pathogens causing infection in marine fish was for $A$. hydrophila followed by $V$. alginolyticus, and PS. fluorescens. While the minimal prevalence was for Ps. aeruginosa and $V$. cholerae. The higher rate of infection was in summer, while the minimal incidence was in winter. Ciprofloxacin was considered the drug of choice for treatment and prevention of bacterial infection in marine fish either alone or combined with other antibiotics.

\section{Acknowledgement}

We would like to express our deep thanks and appreciation to EL Abbassa fish farm, EL sharkia, Egypt for providing T. zillii fish for the experimental infection.

\section{Author's Contributions}

Elsayed, M.E. and A.M. Essawy: Designed the research plan, organized the study and critical review.

I.I. Shabana and M.E. Abou El-Atta: Participated in all experiments, coordinated the data-analysis and contributed to the writing of the manuscript.

N.I. EL-Banna: Participated in all experiments and contributed to the writing of the manuscript.

\section{Ethics}

The authors confirmed that this manuscript is an original work and do not contain any conflict of interest.

\section{References}

Abd-El-Malek, AM., 2017. Incidence and virulence characteristics of Aeromonas spp. in fish. Vet. World, 10: 34-37. DOI: 10.14202/vetworld.2017.34-37

Aly, S.M., 2013. Risk of antimicrobial misuse. Int. J. Health Sci. Qassim Uni., 7: 5-7.

DOI: 10.12816/0006014

Austin, B. and DA. Austin, 1999. Bacterial Fish Pathogens: Disease of Farmed and Wild Fish. 3rd Edn., Springer Science and Business Media, Berlin, ISBN-10: 1852331208, pp: 457.

Austin, B. and D.A. Austin, 2007. Bacterial Fish Pathogens: Disease of Farmed and Wild Fish. 4th Edn., Springer Science and Business Media, UK, ISBN-10: 1402060696, pp: 552.

Bergey's, 2005. Bergey's Manual ${ }^{\circledR}$ of Systematic Bacteriology. 1st Edn., Springer.

Blanco, M.M., A. Gibello, A.I. Vela, M.A. Moreno and L. Domínguez et al., 2002. PCR detection and PFGE DNA macrorestriction analyses of clinical isolates of Pseudomonas anguilliseptica from winter disease outbreaks in sea bream Sparus aurata. Dis. Aquat. Organ., 21: 19-27. DOI: 10.3354/dao050019

Buller, N.B., 2004. Bacteria from Fish and other Aquatic Animals: A Practical Identification Manual. 1st Edn., CAB International Publishing, Cambridge, Oxford Shire, UK, ISBN-10: 0851997384, pp: 361.

Di, D.Y., A. Lee, J. Jang, D. Han and H.G. Hur, 2017. Season-specific occurrence of potentially pathogenic vibrio spp. on the southern coast of South Korea. Applied Environ. Microbiol., 83: 1-13. DOI: 10.1128/AEM.02680-16

Eissa, A.E., N.A. Tharwat and M.M. Zaki, 2013. Field assessment of the mid winter mass kills of trophic fishes at Mariotteya stream, Egypt: Chemical and biological pollution synergistic model. Chemosphere, 90: 1061-1068.

DOI: 10.1016/j.chemosphere.2012.09.010 
Falaise, C., C. François, M.A. Travers, B. Morga and J. Haure et al., 2016. Antimicrobial compounds from eukaryotic microalgae against human pathogens and diseases in aquaculture. Mar Drugs, 2: 1-27. DOI: $10.3390 / \mathrm{md} 14090159$

Grande, B.M.J., J.L. Romero, P.R. Pérez, M.A. Cobo and A. Gálvez et al., 2018. Analysis of potential risks from the bacterial communities associated with air-contact surfaces from tilapia (Oreochromis niloticus) fish farming. Environ. Res., 160: 385-390. DOI: 10.1016/j.envres.2017.10.021

Hayes, J., 2000. Disease of fish spring 2000 Term project Oregon State University. MB52.

Kannapiran, E., J. Ravindran, R. Chandrasekar and A. Kalaiarasi, 2009. Studies on luminous, Vibrio harveyi associated with shrimp culture system rearing Penaeus monodon. J. Environ. Biol., 30: 791-795. PMID: 20143707

Kayansamruaj, P., H.T. Dong, I. Hirono, H. Kondo and S. Senapin et al., 2017. Genome characterization of piscine 'Scale drop and muscle necrosis syndrome'associated strain of Vibrio harveyi focusing on bacterial virulence determinants. J. Applied Microbiol., 124: 652-666. DOI: 10.1111/jam.13676

Lee, S.W. and W. Wendy, 2017. Antibiotic and heavy metal resistance of Aeromonas hydrophila and Edwardsiella tarda isolated from red hybrid tilapia (Oreochromis spp.) coinfected with motile Aeromonas septicemia and edwardsiellosis. Vet. World, 10: 803-807.

DOI: $10.14202 /$ vetworld.2017.803-807

Lukkana, M., J. Wongtavatchai and R. Chuanchuen, 2012. Class 1 integrons in Aeromonas hydrophila isolates from farmed Nile tilapia (Oreochromis nilotica). J. Vet. Med. Sci., 74: 435-40.

DOI: 10.1292/jvms.11-0441

Maalej, S., A. Mahjoibi, C. Alazri and S. Dukan, 2003. Simultaneous effects of environmental factors on motile Aeromonas dynamics in an urban effluent and in the natural seawater. Water Res., 37: 2865-2874. DOI: 10.1016/S0043-1354(03)00117-9

Mahmoud, M.A., M. Abdelsalam, O.A. Mahdy, H.M.F. El Miniawy and Z.A.M. Ahmed et al., 2016. Infectious bacterial pathogens, parasites and pathological correlations of sewage pollution as an important threat to farmed fishes in Egypt. Environ. Pollut., 219: 939-948.

DOI: 10.1016/j.envpol.2016.09.044
Miguéis, S., A.T. Moura, C. Saraiva and A. Esteves, 2016. Influence of season and type of restaurants on sashimi microbiota. Eur. J. Public Health, 26: 877-881. DOI: 10.1093/eurpub/ckw009

Nam, I.Y. and K. Joh, 2007. Rapid detection of virulence Factors of Aeromonas isolated from a Trout farm by Hexaplex-PCR. J. Microbiol., 45: 297-304. PMID: 17846582

Schaperclaus, W., H. Kulow and K. Schreckenbech, 1992. Fish diseases Vol. 1. AA. Balkema/rotterde.

Schmidt, V., M. Gomez-Chiarri, C. Roy, K. Smith and L. Amaral-Zettler, 2017. Subtle microbiome manipulation using probiotics reduces antibioticassociated mortality in fish. mSystems, 2: 1-13. DOI: $10.1128 / \mathrm{mSystems.00133-17}$

Thomas, J., S. Thanigaivel, S. Vijayakumar, K. Acharya and D. Shinge et al., 2014. Pathogenecity of Pseudomonas aeruginosa in Oreochromis mossambicus and treatment using lime oil nanoemulsion. Colloids Surf. B Biointerfaces, 116: 372-377. DOI: 10.1016/j.colsurfb.2014.01.019

Toranzo, A.E., B. Magariños and J.L. Romalde, 2005. A review of the main bacterial fish diseases in mariculture systems. Aquaculture, 246: 37-61. DOI: $10.1016 /$ j.aquaculture.2005.01.002

Ullmann, D., G. Krause, D. Knabner, H. Weber and L. Beutin, 2005. Isolation and Characterization of potentially human pathogenic, cytotoxin-producing aeromonas strains from retailed seafood in Berlin, Germany. J. Vet. Med., 52: 82-87. DOI: $10.1111 /$ j.1439-0450.2005.00820.x

Wang, Y.H., N. Salam, Q. Liu, Z.W. Yang and L.X. Cao et al., 2017. Symbiotic bacteria associated with puffer fish Gastrophysus spadiceus and evaluation of their antimicrobial activities. 3 Biotech., 7: 366-366. DOI: 10.1007/s13205-017-0989-x

Zorrilla, I., M. Chabrillón, S. Arijo, P. Díaz-Rosales and E. Martínez-Manzanares et al., 2003. Bacteria recovered from diseased cultured gilthead sea bream (Sparus aurata L.) in southwestern Spain. Aquaculture, 218: 11-20. DOI: $10.1016 / \mathrm{S} 0044-8486(02) 00309-5$ 